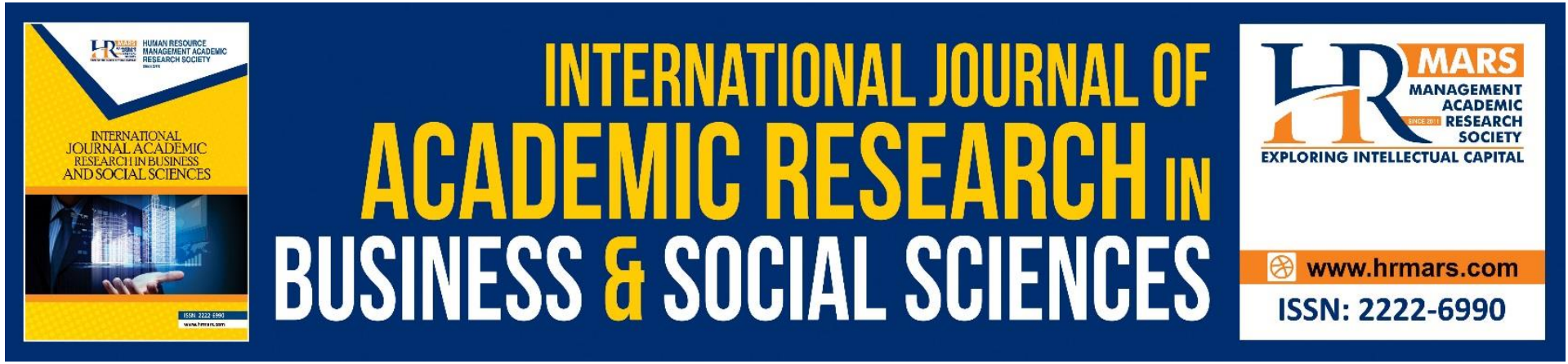

\title{
Motivation in Foreign Language Learning among Malay Undergraduates in a Malaysian Public University
}

Gan Kiat Chien, David Loh Er Fu, Eng Sze Boon, Soo Yew Phong, Lai Yuh Ying

To Link this Article: http://dx.doi.org/10.6007/IJARBSS/v11-i7/10432

DOI:10.6007/IJARBSS/v11-i7/10432

Received: 09 May 2021, Revised: 12 June 2021, Accepted: 27 June 2021

Published Online: 08 July 2021

In-Text Citation: (Chien et al., 2021)

To Cite this Article: Chien, G. K., Fu, D. L. E., Boon, E. S., Phong, S. Y., \& Ying, L. Y. (2021). Motivation in Foreign Language Learning among Malay Undergraduates in a Malaysian Public University. International Journal of Academic Research in Business and Social Sciences, 11(7), 162-168.

Copyright: @ 2021 The Author(s)

Published by Human Resource Management Academic Research Society (www.hrmars.com)

This article is published under the Creative Commons Attribution (CC BY 4.0) license. Anyone may reproduce, distribute, translate and create derivative works of this article (for both commercial and non-commercial purposes), subject to full attribution to the original publication and authors. The full terms of this license may be seen

at: http://creativecommons.org/licences/by/4.0/legalcode

Vol. 11, No. 7, 2021, Pg. 162 - 168

http://hrmars.com/index.php/pages/detail/IJARBSS

JOURNAL HOMEPAGE

Full Terms \& Conditions of access and use can be found at http://hrmars.com/index.php/pages/detail/publication-ethics 


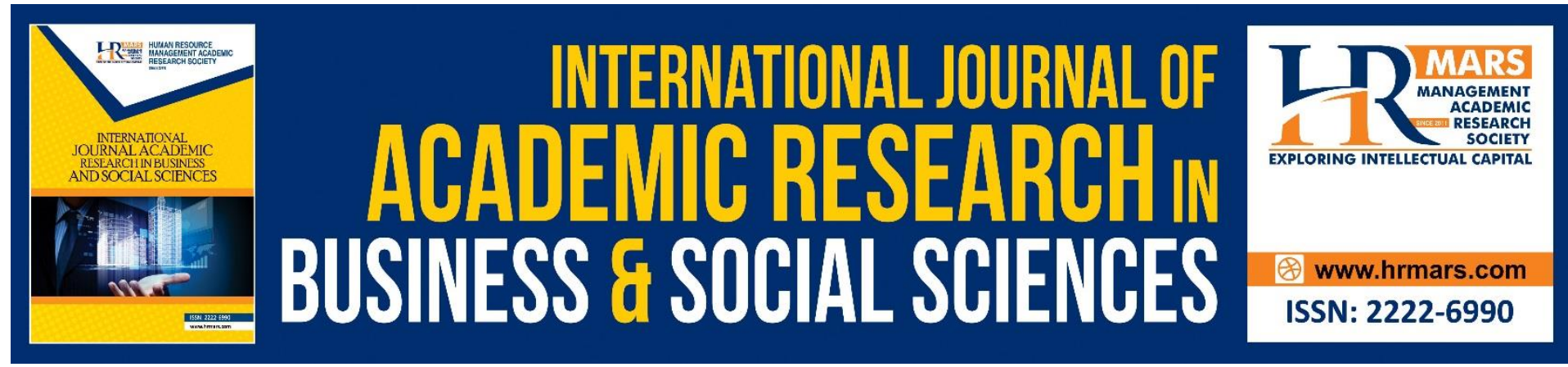

\title{
Motivation in Foreign Language Learning among Malay Undergraduates in a Malaysian Public University
}

\author{
Gan Kiat Chien, David Loh Er Fu, Eng Sze Boon, Soo Yew \\ Phong, Lai Yuh Ying \\ Universiti Teknologi MARA, Malaysia \\ Email: gan_kiat@uitm.edu.my
}

\begin{abstract}
This study investigated the motivational orientations of undergraduates in learning Mandarin as a foreign language in a Malaysian public university. The subjects were four hundred and twenty-three Malay undergraduates who enrolled in a level three Mandarin course. A 30-item five-point Likert scale questionnaire which integrated Gardner's socio-educational model and Dörnyei's framework of second language (L2) motivation was used to gather data on the respondents' integrative, instrumental and attitudinal motivations. Descriptive and inferential statistics were used to analyze the data. Results indicated that generally the students were highly motivated to learn Mandarin as a foreign language. They were both integratively and instrumentally motivated but were more oriented towards attitudinal motivation in learning Mandarin as a foreign language. Moreover, the students were more inclined towards the teacher-specific than the course-specific and group-specific sources of attitudinal motivation in learning Mandarin. These results offer useful practical instructional implications concerning the students' motivational orientations in the Mandarin language classroom.
\end{abstract}

Keywords: Mandarin Language Learning, Motivational Orientations, Attitudinal, Integrative, Instrumental

\section{Introduction}

Interest in learning the Mandarin language has increased tremendously in many countries in the world. The number of people learning Chinese language is increasing very fast, according to a recent report from the Xinhua News Agency, there are currently "more than 100 million foreign speakers and learners of Mandarin worldwide with 350,000 foreigners studying Chinese language in 746 Chinese universities last year." (14/July/2014). In 2004, there were less than 30 million Mandarin learners worldwide, and by 2015, there were 120 million. This phenomenon can also be seen in Malaysian public universities where the number of students learning Mandarin has been growing rapidly, specifically in Universiti Teknologi MARA (UiTM), the biggest university with thirty-eight branch campuses throughout Malaysia where most of the students are Malays. The students' registration system of the university (SiMS) shows that 19,568 students enrolled for Chinese language classes at the end of 2020. 
The Mandarin language has always been the most popular elective subjects among other foreign languages. The rise of China as an economic superpower has made Mandarin a preferred second or foreign language worldwide. In the Malaysian context, the popularity of Mandarin among the Malay undergraduates is due to an added value in dealing with Mandarin speaking businessmen, job opportunities, and the recognition of its significance in a multi-racial country.

One of the notable problems with learning Mandarin as a foreign language among undergraduates is their limited ability in speaking. Some factors which affect their ability to learn this language are interference of mother tongue, insufficient learning time, learning environment (Cheun, 2006), lack of vocabulary (Tan \& Hoe, 2009) and psychological reasons (Tan \& Hoe, 2007). In view of the increasing expectations for graduates to be knowledgeable and proficient in Mandarin, there is a need to conduct more research in this area particularly concerning the motivation of Malay undergraduates to learn Mandarin as a foreign language at institutions of higher learning in Malaysia.

\section{Statement of the Problem}

Learning Mandarin as a foreign language has become increasingly popular among undergraduates in tertiary institutions in Malaysia in general and in Universiti Teknologi MARA specifically. Non-Chinese learners will face difficulties learning Mandarin due to the distinct pronunciation and pictographic characters. The difference between Mandarin and other alphabetic languages, like Malay and English is that the challenge for learners whose native language is not closely related to Mandarin increases. For example, in Chinese character learning, Sung and Wu (2011) have listed three challenges which non-Chinese may face in learning Mandarin; the large number of characters to be acquired before becoming literate, the lack of correspondence between a character and its pronunciation and many characters with different meanings share the same sound. As a result, the learners need to be motivated to counter the challenges.

Research on learners' motivation have produced inconclusive findings regarding their motivational orientations in learning foreign languages. Some studies found integrative motivation to be favoured by foreign language learners while other studies found learners to be more oriented towards instrumental motivation. Yet other studies have shown that learners are equally inclined towards both types of motivation in foreign language learning. Moreover, learners' attitudes have become a mediating factor in motivating students to learn foreign languages and can affect a learner's overall performance in language acquisition. Not much research has investigated attitudinal motivation together with integrative and instrumental motivation in learning foreign languages. Most research focus on integrative and instrumental motivation based on Gardner's socio-educational model. Therefore, there is a need to investigate all these three motivational orientations, viz integrative, instrumental and attitudinal motivations, among non-Chinese undergraduates learning of Mandarin as a foreign language based on an integration of Gardner's (1985) socio-educational model and Dörnyei's (1994) expanded framework of L2 motivation in light of the problems and difficulties they experience in learning this complex language as well as to provide further empirical evidence to gain more insights into the inconsistent findings regarding learners' motivational orientations in learning foreign languages. 


\section{Research Objectives}

The objectives of this study are to examine the motivational orientation of undergraduates in learning Mandarin as a foreign language in a Malaysian public university. Based on the research objectives, the research questions (RQ) are as follow:

RQ1: What is the level of integrative motivation, instrumental motivation, and attitudinal motivation for learning Mandarin as a foreign language among undergraduates?

RQ2: Is there a significant difference among the integrative motivation, instrumental motivation, and attitudinal motivation of undergraduates learning Mandarin as a foreign language?

RQ3: Is there a significant difference between the three types of attitudinal motivation of students learning Mandarin as a foreign language?

\section{Literature Review \\ Motivations in Foreign Language Learning}

Learners' motivation is an essential element in learning a foreign language. It is related to the desire to exert one's effort to successful learning the target language. Without motivation, learners will not persist in all the hard work needed to acquire the language. How to motivate or stimulate learners' desire to learn is one of the vital aspects in language acquisition. Hence, it is important to study learners' motivation orientations in developing appropriate motivating strategies in the language classroom.

Early research on language learning motivation was initiated by social psychologists because of their recognition of the social and cultural dimension of L2 motivation (Dörnyei, 2003). Gardner and his associates' language motivation model are the most influential framework in the social psychology domain (Gardner, 1985). The model specifically focuses on two types of motivation, integrative motivation, and instrumental motivation. Integrative motivation is related to positive perspective toward the target language community. A learner is integratively motivated to learn the language because he/she appreciates, admires, interested to interact with, and wishes to be accepted as a member of the community eventually (Gardne \& Lambert, 1972). Integrative motivation causes learners to want to learn more about the target language culture, connect with members of the cultural group, and integrate into the target language group. It was the most stressed by Gardner as he discovers a strong connection between integrative motivation and L2 learning achievement in his early research (Gardner, 1985; Gardner, Day \& Maclntyre, 1992; Gardner \& Lambert, 1972; Gardner \& Maclntyre, 1991; Gardner, Tremblay \& Masgoret, 1997; Masgoret \& Gardner, 2003).

In contrast to integrative motivation, instrumental motivation is associated to gaining practical advantage or value from learning a new language (Lambert, 1974), such as applying for a job, getting a higher salary, meeting the requirement of university, or reading technical material. The integrative motivation is related to the affective and emotional aspect to the other language community whereas the instrumental motivation involves the necessity and rewards of learning a language. 
Numerous studies have also reported a positive relationship between integrative motivation and successful language learning. For example, a study has been conducted to examine the motivation types of 95 Iranian English as a Foreign Language (EFL) students in a high school. Results indicates that most of the high achievers (92.9\%) had high integrative motivation. It also revealed that integratively motivated students outperformed instrumentally motivated students by a significant margin (Gholami, Allahyar \& Rafik-Galea, 2012).

A study on Arabic language students in Nigerian universities indicated that they have a strong integrative orientation, they also demonstrate a positive interaction with their instructors and a strong interest in the Arabic course. Nevertheless, their motivation to Arabic and instrumentality are very low because they do not believe learning the language would help them find a good job or enable them to accomplish their goals in the career path.

Most research have come to the same conclusion that integrative orientation is crucial for good language achievement. Nevertheless, in Gardner and Maclntyre's (1991) later studies, they found that instrumental motivation was also effective in learning a language, and integrative motivation is not always superior to instrumental motivation. According to Dörnyei (1990), instrumental motivations significantly contribute to motivation in foreign language learning contexts. He said integrative motivation is not relevant for foreign language learners because they hardly can engage with the target language community members. As a result, they have no dedication or interest to integrate into that culture.

A study was conducted on EFL university students in Indonesia to investigate their motivational orientations (Setiyadi, 2019). Results indicated that integrative motivation, which has been established in ESL settings where group integration is a concern, is not applicable to Indonesian EFL learners. His findings corroborate with several research that the EFL students are interested in learning English as it is a lingua franca in the era of globalisation, but without any interest in integrating with people from Anglophone countries (Setiyadi \& Sukirlan, 2016; Lamb, 2004).

Other studies also reported that instrumental purpose, such as using English to get a better job or study abroad, are highly motivating for English students (Ozgür \& Griffiths, 2013). In a study conducted in Iran, findings indicated that instrumental motivation was higher than integrative motivation among EFL students as they recognised the significance of English in their academic achievement. (Sheibani, 2012). Another study had been conducted in Malaysia to investigate the learning orientation of Malay university students learning Mandarin as a foreign language (Tan, Ooi \& Ismail, 2012). The result revealed that the students were strongly motivated by instrumental goals, especially for improving their chances of getting a job.

A review is provided by Hong (2017) from a qualitative research on 12 English as a Second Language (ESL) students in a secondary school in Malaysia. The primary purpose of this study was to look at ESL students' instrumental and integrative motivation for learning English. According to the results of this study, students are more instrumentally motivated in ESL learning than integratively motivated. However, the data also reveals that instrumentally oriented students do not dedicate much time to learning English. Among the students, integratively motivated students are willing to read beyond their textbook and learn after English classes for the purpose of attaining the highest level of English proficiency. The 
researchers concluded that integrative motivation is found to have a bigger difference on good ESL test performance, which is in line with a study conducted by Özgür and Griffiths (2013).

There are also studies that showed that integrative and instrumental motivations are equally important in learning foreign languages among undergraduates in Iran (Choubsaz \& Choubsaz, 2014), in Malaysia (Chua \& Affiq, 2019; Khong, Hassan \& Ramli, 2017; Ainol \& Isarji, 2009) and in the Philippines (Gonzales, 2010). This is congruent with Brown's (2000) contention that second or foreign learners are neither integratively nor instrumentally motivated but have a combination of both motivational orientations.

Deng's (2015) study explores how integrative, instrumental, and attitudinal motivations play a role in the process of Chinese language acquisition, and how each of them influences Chinese language learners' outcomes. Results indicated that neither integrative nor instrumental motivation was significant in predicting the Chinese learning outcomes. However, attitudinal motivation was a significant predictor of the students' Chinese learning outcomes.

Previous literature shows that both integrative and instrumental language motivation play important roles in the language classroom. However, there is no consistent viewpoint about which form of motivation is preferable to the other. The significance of one form of motivation over another can differ depending on the circumstances being studied. In a second language setting, students are more likely to have integrative motivation, while in a foreign language setting, they are more likely to have instrumental motivation.

\section{Gardner's Socio-educational Model of Motivation and Dörnyei's Expanded Framework of L2 Motivation}

Gardner's (1985) socio-educational model has been a pioneering and influential L2 motivation model and has been used to test many hypotheses in the field of language motivation for more than two decades in the form of the Attitude/Motivation Test Battery (AMTB). This model comprises three main components: a) Integrativeness, attitudes toward the learning situation and motivation. Integrativeness is seen as an interest, identification with the second language community, with their culture and beliefs; b) Attitudes toward the learning situation involve attitudes toward the school, reactions to the textbooks, etc. c) Motivation is the effort exerted to learn the material, desire plus positive attitudes in learning the material. It also includes the additional component of instrumentality which refers to learning a language for practical reasons. According to Gardner (2005), instrumentality and integrativeness are mediated by motivation.

Dörnyei (1994) noted that the construct of attitudes toward the learning situation lacked specific contents in Gardner's model. Therefore, he added a number of specific situational motives and components to Gardner's attitudes toward the learning situation such as teacher specific, course-specific, and group-specific motives which are rooted in the various aspects of language learning in a classroom setting from his expanded framework of L2 motivation. These specific situational motives are seen in terms of attitudinal motivational components that are specific to learning situations. Teacher-specific motivational components are related to the teacher's personality, teaching style, and relationship with the students. Course- 
specific motivational components are related to the syllabus, the teaching materials, the teaching method, and the learning tasks. Group-specific motivational components are related to the learners group dynamics in the class which can be classified into goal-orientedness, norm and reward system, group cohesion, and classroom goal structures.

\section{Attitudes in Foreign Language Learning}

Dogan \& Tuncer (2020) define foreign language attitudes as an individual's attitudes towards any foreign language, all learning contexts and processes related to that language, the speakers of that language and the culture in which that language is spoken. It also includes a set of values that the student brings to the experience of learning a foreign language which is shaped by the successful results that the student hopes and the advantages which can be reaped from learning that language (Chambers, 1999). These values are determined by the student's experience in learning the target language, travel experience, and the influence of parents, friends, and even speakers of that language. Hence, attitudes in foreign language learning involves the social, cultural, and educational factors that can affect the language learners.

In the context of the role of attitudes in foreign language learning, language learning would be unproductive if students do not have positive attitudes to support it (Gardner, 2010; Dörnyei, 2005). Merisuo-Storm (2007) states that students' positive attitudes towards language learning can increase their motivation and foster their language learning. Literature abounds in emphasizing that students who have positive attitudes toward a language and its speakers and culture are more successful than those who have negative attitudes (Brown, 2000; Atchade, 2002; Csizer \& Dörnyei, 2005; Elyildirim \& Ashton, 2006; Brown, 2007; Fakeye, 2010; Garrett, 2010; Yu, 2010; Bartram, 2010; Oroujlou \& Vahedi, 2011; Youssef, 2012; Abidin et al., 2012).

In sum, attitudes toward the learning situation play an important role in a learner's overall language acquisition performance. Positive attitudes toward the learning situation are more likely to contribute to improved enjoyment, eagerness, and engagement in the language learning process.

\section{Methodology}

\section{Research Framework}

This study employed the Gardner's (1985) socio-educational model and Dörnyei's (1994) framework of L2 motivation to investigate the L2 learners' motivations in learning foreign language. A research model is proposed as depicted in Figure 1. 


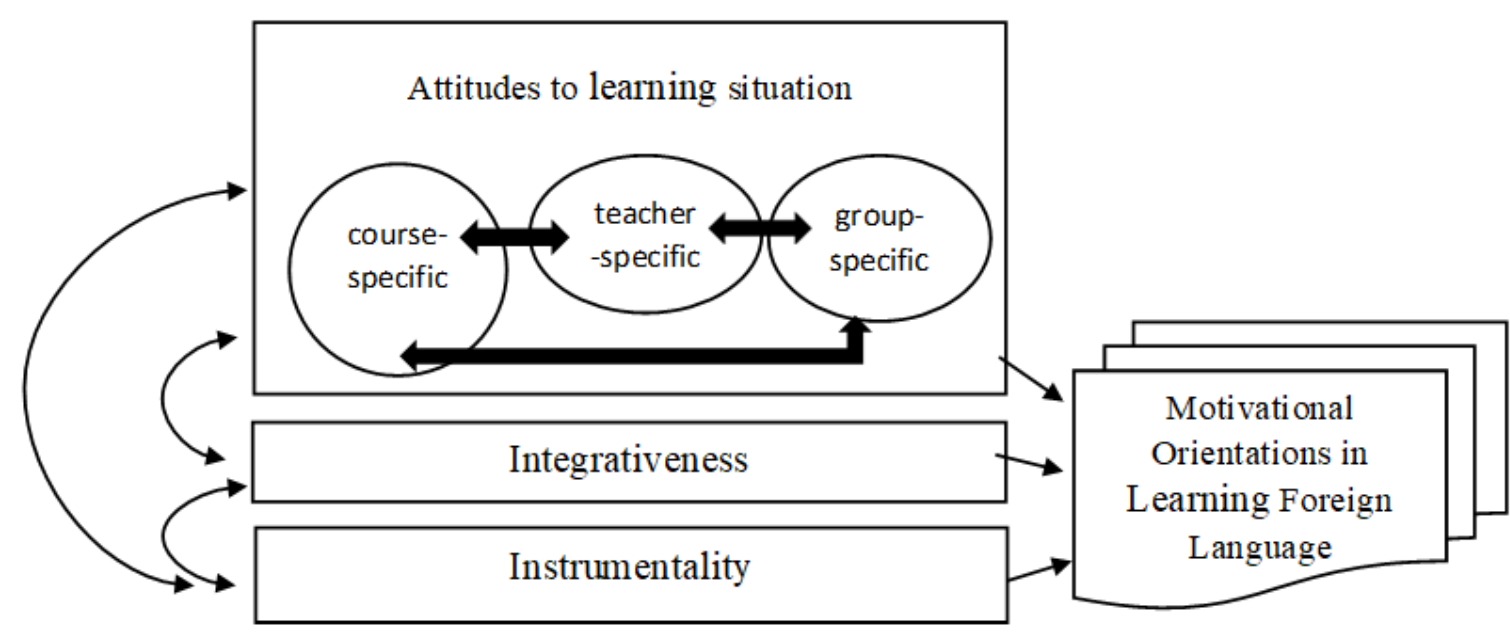

Figure 1. Research model

The research model shows how the variables such as instrumentality, integrativeness, and attitudes to learning situation are referred to as instrumental, integrative, and attitudinal motivations respectively. Attitudinal motivation is divided into course-specific, teacherspecific, and group-specific motivations.

\section{Population and Sample}

A sample of four hundred and twenty-three $(\mathrm{N}=423)$ degree students from Universiti Teknologi MARA, Cawangan Melaka (Malacca state campus) were randomly selected from the total population of 625 students to participate in this study. The sample comprised students who enrolled in the Introductory Mandarin Level III as their foreign language course and had enrolled in the same courses for level I and level II. All the participants were Malay students, ranging between 20 and 27 years old. The sample consisted of 126 males and 297 females who were non-native Mandarin speakers. They were undergraduates of different courses from 7 faculties such as Business Administration ( $N=174)$, Art \& Design $(\mathrm{N}=12)$, Accountancy $(\mathrm{N}=26)$, Hotel and Tourism Management $(\mathrm{N}=23)$, Communication and Media $(\mathrm{N}=15)$, Computer Science and Mathematics $(\mathrm{N}=35)$, and Plantation and Agrotechnology $(\mathrm{N}=138)$. Although the sample in this study were from the same university, they came from different states in Malaysia and had different education and socio-economic backgrounds before entering the university; therefore, they are expected to bring along different attitudes toward the learning Mandarin as a foreign language. Moreover, the fact that they pursue knowledge in different faculties also provided a variety of perceptions about their learning of Mandarin.

\section{Instrument}

A questionnaire which integrated Gardner's socio-educational model and Dörnyei's framework of L2 motivation was adopted from Deng (2015) and used to gather data on the respondents' integrative, instrumental, and attitudinal motivations in learning Mandarin language in the classroom setting. The attitude/ motivation scales of the original 6-point Likert Scale format of Gardner's AMTB item-key document, were adapted to a 5-point scale. The questionnaire for this study comprised two parts. Part one consisted of 5 items while part two consisted of 30 items. The first part of the questionnaire was the respondents' 
demographics and educational background. The second part of the questionnaire consisted of the integrative, instrumental and attitudinal orientation of motivation in learning Mandarin language, measured on a five-point Likert scale, ranging from 1 (Strongly Disagree) to 5 (Strongly Agree).

For the section two of the questionnaire, integrative orientation scale includes 10 items and the respondents are asked to measure their integrativeness or interest to assimilate with the target language, such as positive disposition towards speakers of the community of the target language, etc. On the instrumental orientation scale, there are 10 items to find out their utilitarian reasons for learning Mandarin as a foreign language, for instance future job's requirements, better career options, economy opportunity, etc. Meanwhile, the attitudinal orientation scale has 10 items to investigate student's attitudes toward choosing Mandarin language as a foreign language courses in university level. The 10 items for attitudinal orientation scale included 3 type of subscales motivation: teacher-specific (4 items), coursespecific ( 4 items) and group-specific ( 2 items).

\section{Reliability Test}

The Cronbach's Alpha Reliability test was conducted to test the internal consistency of the study instrument. Results of the tests are presented in Table 1.

Table 1. Reliability Coefficient of Study Instruments

\begin{tabular}{|l|c|c|}
\hline \multicolumn{1}{|c|}{ Instrument } & No. of Items & Cronbach's Alpha \\
\hline Integrative & 10 & 0.85 \\
\hline Instrumental & 10 & 0.78 \\
\hline Attitudinal & 10 & 0.90 \\
\hline Overall & 10 & 0.93 \\
\hline
\end{tabular}

Cronbach's alpha values for instruments in Table 1 are greater than 0.70 . Therefore, the scale of all the items can be considered as having high reliability since they are all greater than 0.75 .

\section{Procedures}

To collect data, a survey questionnaire was developed based on Gardner's (1985) socioeducational model and Dörnyei (1994) framework of L2 Motivation. A pilot test was conducted to assess the reliability and validity of the instrument with randomly selected respondents $(\mathrm{N}=20)$ from heterogeneous groups. The pilot test showed that Cronbach's Alpha reliability for the total of 30 items was between 0.78 to 0.90 . During the completion process of the questionnaire, the purpose of the study was explained before the distribution by the respondents' class Mandarin lecturers explained to their respective students the purpose of the questionnaire and informed them that the information they gave were confidential and would be used for research purposes only. There were 423 students out of a total of 625 population $(67.7 \%)$ involved in this study.

\section{Data Analysis}

The data collected from the questionnaire in this study were analyzed using the Statistical Package for Social Sciences (SPSS-v-17) software. Descriptive statistics of means and standard deviations and inferential statistics of one-way within subject analysis of variance (ANOVA) were used to analyze the data. 


\section{Results}

This section presents the analysis and findings of the integrative, instrumental, and attitudinal motivation level of Malay undergraduates in learning Mandarin as a foreign language. The results are presented according to the research questions.

$R Q$ 1: What is the level of integrative motivation, instrumental motivation, and attitudinal motivation for learning Mandarin as a foreign language among undergraduates?

Table 2. Means and Standard Deviations Values on Integrative, Instrumental, Attitudinal and Overall Motivation

\begin{tabular}{|l|c|c|}
\hline \multicolumn{1}{|c|}{ Motivation } & Mean (M) & Standard Deviation (SD) \\
\hline Integrative & 4.04 & 0.458 \\
\hline Instrumental & 4.02 & 0.446 \\
\hline Attitudinal & 4.31 & 0.475 \\
\hline Total (Overall) & 4.12 & 0.478 \\
\hline
\end{tabular}

Table 3. Interpretation of Mean Scores on Motivation

\begin{tabular}{clcl}
\hline Scale & Agreement Range & Mean Range & Motivational Level \\
5 & Strongly Agree & $4.50-5.00$ & Very High \\
4 & Agree & $3.50-4.49$ & High \\
3 & Neutral & $2.50-3.49$ & Moderate \\
2 & Disagree & $1.50-2.49$ & Low \\
1 & Strongly Disagree & $1.00-1.49$ & Very Low \\
\hline
\end{tabular}

Based on Tables 2 and 3, the results indicated that the overall level of motivation for learning Mandarin as a foreign language of Malay undergraduates was high ( $M=4.12, S D=0.478)$. Moreover, the level of integrative motivation ( $M=4.04, S D=0.458)$, instrumental motivation $(\mathrm{M}=4.02, \mathrm{SD}=0.446)$ and attitudinal motivation $(\mathrm{M}=4.31, \mathrm{SD}=0.475)$ for learning Mandarin as a foreign language of Malay undergraduates was also high respectively.

The results based on a preliminary inspection/observation of the descriptive statistics in Table 2 and the interpretation of mean scores on motivation (Delgado, 2016) in Table 3 indicated that generally the students were highly motivated to learn Mandarin as a foreign language. Specifically, their attitudinal motivational level was higher than their integrative and instrumental motivation levels. Moreover, their integrative and instrumental motivational levels were similarly high. To confirm these findings, the inferential statistics of one-way within subjects ANOVA was used to determine whether there were statistically significant differences between the three motivational orientations in RQ 2. 
Table 4. Descriptive Statistics by Items of Integrative Motivation

\begin{tabular}{|c|l|c|c|}
\hline $\begin{array}{c}\text { Items } \\
\text { No. }\end{array}$ & \multicolumn{1}{|c|}{ Items } & Mean & $\begin{array}{c}\text { Standard } \\
\text { Deviation }\end{array}$ \\
\hline 1 & It will enable me to easily speak in Mandarin with people. & 3.83 & 0.713 \\
\hline 3 & It will allow me to meet and converse with more and varied people. & 4.01 & 0.660 \\
\hline 5 & It will enhance my understanding of Chinese culture and society. & 4.14 & 0.657 \\
\hline 7 & I will be able to participate more freely in Chinese cultural activities. & 3.83 & 0.768 \\
\hline 9 & $\begin{array}{l}\text { I will be able to enjoy Chinese songs, movies, films, and TV drama } \\
\text { series. }\end{array}$ & 3.84 & 0.831 \\
\hline 11 & $\begin{array}{l}\text { It will enable me to better understand and appreciate the Chinese } \\
\text { way of life. }\end{array}$ & 3.95 & 0.688 \\
\hline 13 & It fulfills my personal interests. & 3.97 & 0.741 \\
\hline 15 & I want to learn as many foreign languages as possible. & 4.34 & 0.691 \\
\hline 17 & I want to learn about other cultures to better understand the world. & 4.12 & 0.662 \\
\hline 19 & It is part of the Malaysia's multi-culture. & 4.33 & 0.649 \\
\hline
\end{tabular}

Table 5. Descriptive Statistics by Items of Instrumental Motivation

\begin{tabular}{|c|c|c|c|}
\hline \begin{tabular}{c|} 
Items \\
No.
\end{tabular} & Items & Mean & $\begin{array}{l}\text { Standard } \\
\text { Deviation }\end{array}$ \\
\hline 2 & I need the class to fulfill my university's requirements. & 4.13 & 0.742 \\
\hline 4 & It will make me a knowledgeable person. & 4.30 & 0.610 \\
\hline 6 & I think it will be useful in getting a good job. & 4.28 & 0.638 \\
\hline 8 & It will enable me to compete effectively in the global economy. & 3.84 & 0.743 \\
\hline 10 & $\begin{array}{l}\text { I would like to use Mandarin when I travel to a Chinese-speaking } \\
\text { country/area. }\end{array}$ & 4.00 & 0.762 \\
\hline 12 & $\begin{array}{l}\text { China is playing a more important role in the economic development } \\
\text { of the world. }\end{array}$ & 3.89 & 0.731 \\
\hline 14 & I will feel proud if I can speak Mandarin. & 4.33 & 0.727 \\
\hline 16 & $\begin{array}{l}\text { My friends/siblings took Mandarin and they recommended the } \\
\text { Mandarin class to me. }\end{array}$ & 3.33 & 1.073 \\
\hline 18 & It is a language that is going to be very useful. & 4.29 & 0.620 \\
\hline 20 & My parents encourage me to learn it. & 3.85 & 0.927 \\
\hline
\end{tabular}


Table 6. Descriptive Statistics by Items of Attitudinal Motivation

\begin{tabular}{|l|c|l|c|c|}
\hline $\begin{array}{l}\text { Attitudinal } \\
\text { Motivation }\end{array}$ & $\begin{array}{c}\text { Items } \\
\text { No. }\end{array}$ & \multicolumn{1}{|c|}{ Items } & Mean & $\begin{array}{c}\text { Standard } \\
\text { Deviation }\end{array}$ \\
\hline \multirow{2}{*}{$\begin{array}{l}\text { Teacher- } \\
\text { specific (TS) }\end{array}$} & 21 & The teacher makes learning fun. & 4.44 & 0.657 \\
\cline { 2 - 5 } & 24 & The teacher's feedback is encouraging. & 4.37 & 0.624 \\
\cline { 2 - 5 } & 25 & Learning is student-centered and interactive. & 4.18 & 0.616 \\
\cline { 2 - 5 } & 28 & $\begin{array}{l}\text { The teacher has the knowledge and skills to teach the } \\
\text { language. }\end{array}$ & 4.57 & 0.591 \\
\hline \multirow{2}{*}{$\begin{array}{l}\text { Course- } \\
\text { specific (CS) }\end{array}$} & 22 & The course material is interesting. & 4.30 & 0.658 \\
\cline { 2 - 5 } & 23 & The course tasks are at the proper level for me. & 4.19 & 0.661 \\
\cline { 2 - 5 } & 29 & $\begin{array}{l}\text { The course activities provide the opportunity for } \\
\text { learning Mandarin. }\end{array}$ & 4.33 & 0.637 \\
\cline { 2 - 5 } & 30 & I can learn the Chinese culture in/out of the classroom. & 4.14 & 0.725 \\
\hline $\begin{array}{l}\text { Group- } \\
\text { specific (GS) }\end{array}$ & 26 & The group-work or pair-work is fun and helpful. & 4.30 & 0.678 \\
\cline { 2 - 5 } & 27 & I enjoy speaking Mandarin with my classmates. & 4.26 & 0.703 \\
\hline
\end{tabular}

An extension of RQ 1 includes the results from the descriptive statistics by items of the integrative, instrumental, and attitudinal motivations of the students as shown in Tables 4, 5, and 6 respectively. Based again on the interpretation of mean scores of motivation in Table 3 , comparison between the mean scores of the students' integrative motivation in Table 4 illustrated that students were at the upper ends of their high level of motivation for items 15, 19 , and 5 namely "I want to learn as many foreign languages as possible, "It is part of the Malaysia's multi-culture", and "It will enhance my understanding of Chinese culture and society" respectively. Comparison between the mean scores of the students' instrumental motivation in Table 5 indicated that students were at the upper ends of their high level of motivation for items 14, 4, 18, and 6 which were "I will feel proud if I can speak Mandarin", "It will make me a knowledgeable person", "It is a language that is going to be very useful", and "I think it will be useful in getting a good job" respectively. As for attitudinal motivation in Table 6, the teacher specific subscale reported items $28,21,24$, and 25 with upper ends of high motivational level. Course specific attitudinal motivation recorded upper bounds of high motivational level for items 29 and 22 respectively viz. "The course activities provide the opportunity for learning Mandarin" and "The course material is interesting". Group specific attitudinal demonstrated that items 26 and 27 yielded upper bounds of high level of motivation for items 26 and 27 which were "The group work or pair-work is fun and helpful" and "I enjoy speaking Mandarin with my classmates".

RQ2: Is there a significant difference between the integrative motivation, instrumental motivation, and attitudinal motivation of undergraduates learning Mandarin as a foreign language? 
Table 7. One-Way Within-Subjects Analysis of Variance of Means in Motivational Orientation by Types

\begin{tabular}{cccccc}
\hline Source & SS & df & MS & F & P \\
\hline Types & 21.734 & 1.826 & 11.901 & 188.366 & .000 \\
Error & 46.692 & 770.715 & .63 & & \\
\hline
\end{tabular}

Table 8. ANOVA Comparisons of Means in Motivational Orientation by Types

\begin{tabular}{|c|c|c|c|c|c|c|}
\hline \multirow[b]{2}{*}{ Motivation } & \multirow[b]{2}{*}{$\mathbf{N}$} & \multirow[b]{2}{*}{$\mathbf{M}$} & \multirow[b]{2}{*}{ SD } & \multicolumn{3}{|c|}{ Bonferroni Post Hoc Test Comparisons } \\
\hline & & & & Integrative & Instrumental & Attitudinal \\
\hline Integrative & 423 & 4.036 & .458 & & .382 & $.000 *$ \\
\hline Instrumental & 423 & 4.024 & .446 & .382 & & $.000 *$ \\
\hline Attitudinal & 423 & 4.307 & .475 & $.000 *$ & $.000 *$ & \\
\hline
\end{tabular}

*The mean difference is significant at the 0.05 level

Table 7 shows that there was a statistically significant difference between the three motivational orientations as determined by one-way within-subjects ANOVA (F (1.826, $770.715)=188.366, p=.000)$. Therefore, the null hypothesis that there is no significant difference between integrative motivation, instrumental motivation, and attitudinal motivation of students learning Mandarin as a foreign language in UiTM Melaka was rejected. Bonferroni post hoc test of pairwise comparisons in Table 8 revealed that there was a significant difference between attitudinal motivation $(M=4.307, S D=0.475)$ and integrative motivation $(M=4.036, S D=0.458)$ as well as instrumental motivation $(M=4.024, S D=0.446)$ at $\alpha$ level= .005. However, there was no significant difference between integrative motivation and instrumental motivation at $\alpha$ level $=.005$.

These results suggest that the students were more oriented towards attitudinal than integrative and instrumental motivation in learning Mandarin as a foreign language. However, they were both integratively and instrumentally motivated in learning Mandarin as a foreign language.

RQ3: Is there a significant difference between the three types of attitudinal motivation of students learning Mandarin as a foreign language?

Table 9. One-Way Within-Subjects Analysis of Variance of Means in Attitudinal Motivation

\begin{tabular}{ccrrrc}
\multicolumn{7}{c}{ by Types } \\
\hline Source & SS & df & MS & F & P \\
\hline Types & 5.253 & 1.803 & 2.913 & 25.775 & .000 \\
Error & 85.997 & 760.896 & .113 & & \\
\hline
\end{tabular}


Table 10. ANOVA Pairwise Comparisons of Means in Attitudinal Motivation by Types

\begin{tabular}{|c|c|c|c|c|c|c|}
\hline \multirow[b]{2}{*}{$\begin{array}{l}\text { Attitudinal Motivation } \\
\text { (Types) }\end{array}$} & \multirow[b]{2}{*}{$\mathbf{N}$} & \multirow[b]{2}{*}{ M } & \multirow[b]{2}{*}{ SD } & \multicolumn{3}{|c|}{ Bonferroni Post Hoc Test Comparisons } \\
\hline & & & & $\begin{array}{l}\text { Teacher- } \\
\text { Specific } \\
\text { (TS) }\end{array}$ & $\begin{array}{c}\text { Course- } \\
\text { Specific (CS) }\end{array}$ & $\begin{array}{c}\text { Group- } \\
\text { Specific (GS) }\end{array}$ \\
\hline Teacher-Specific (TS) & 423 & 4.391 & .491 & & $.000 *$ & $.000 *$ \\
\hline Course-Specific (CS) & 423 & 4.240 & .534 & $.000 *$ & & .135 \\
\hline Group-Specific (GS) & 423 & 4.275 & .615 & $.000 *$ & .135 & \\
\hline
\end{tabular}

*The mean difference is significant at the 0.05 level

A one-way within-subjects ANOVA of the subscales of attitudinal motivation in Table 9 showed that there was a statistically significant difference among the three subscales of attitudinal motivation viz. teacher specific, course specific and group specific ( $F(1.803$, $760.896)=25.775, p=.000)$. Therefore, the null hypothesis that there is no significant difference between the three types of attitudinal motivation of students learning Mandarin as a foreign language in UiTM Melaka was rejected.

Bonferroni post hoc test of pairwise comparisons in Table 10 revealed that there was a significant difference between teacher-specific attitudinal motivation $(M=4.391, S D=0.491)$ and course-specific attitudinal motivation $(M=4.240, S D=0.534)$ at $\alpha$ level $=.005$. Moreover, there was also a significant difference between teacher-specific attitudinal motivation ( $M=$ $4.391, S D=0.491)$ and group-specific attitudinal motivation $(M=4.275, S D=0.615)$ at $\alpha$ level $=.005$. However, there was no significant difference between course-specific attitudinal motivation and group-specific attitudinal motivation at $\alpha$ level $=.005$.

These results suggest that the students were more oriented towards the teacher-specific than the course-specific and group-specific sources of attitudinal motivation in the learning situation. Moreover, they were similarly oriented towards the course-specific and groupspecific sources of attitudinal motivation in the learning situation.

\section{Discussion}

Overall, the study found that students were highly motivated to learn Mandarin as a foreign language. Specifically, they had both high level of integrative and instrumental motivations in learning a foreign language which concurs with the findings of Ainol \& Isarji (2009); Gonzales (2010); Choubsaz \& Choubsaz (2014); Khong, Hassan \& Ramli (2017) and Chua \& Mohammad Affiq (2019). This finding reaffirms/supports Brown's (2000) assertion that both integrative and instrumental motivations were not mutually exclusive in that learners rarely selected one form of motivation when learning a second or foreign language, but rather a combination of both orientations. The study demonstrated that students' instrumental motivation was more inclined towards a feeling of pride in being able to speak Mandarin, making them a knowledgeable person, and securing a good job. On the other hand, integrative motivation was more oriented towards being multilingual and part of the Malaysian multi-cultural society as well as enhancing their understanding of Chinese culture and society. This is contrary to Dörnyei's (1990) contention that integrative motivation is less relevant than instrumental motivation for foreign language learners because they do not have sufficient experience with the target community and they are, therefore, not committed to integrating into that group. 
Taken together, these findings imply that both the students' integrative and instrumental motivations supported and complemented each other in maintaining and sustaining their learning of Mandarin as a foreign language.

The study also indicated that the students were more oriented towards attitudinal motivation than integrative and instrumental motivation which suggests that students' attitudes toward the learning situation in terms of situation-specific motives rooted in various aspects of language learning in a classroom setting is a crucial factor in foreign language learning in general and Mandarin language in particular. Specifically, this finding is consistent with the finding in Deng's (2015) study that attitudinal motivation plays a more influential role than integrative and instrumental motivations in the process of Chinese language learning. Generally, this finding concurs with the findings of previous research that the attitudes toward the learning situation is an important factor to affect a learner's overall performance in language acquisition (Brown, 2000; Atchade, 2002; Csizer \& Dörnyei, 2005; Elyildirim \& Ashton, 2006; Brown, 2007; Fakeye, 2010; Garrett, 2010; Yu, 2010; Bartram, 2010; Oroujlou \& Vahedi, 2011; Youssef, 2012; Abidin et al., 2012).

Interestingly, the study found that among the three main types of attitudinal sources within the learning situation, the teacher-specific source was the most dominant. The teacher's specific sources of attitudinal motivation comprise the teacher's competency, studentcentered, interactive, and fun learning approach and encouraging feedback. This finding lends credence to the integral role of teachers in influencing the attitudes towards the learning situation in the Mandarin language classroom.

The findings of the study provide important implications for the teaching and learning of Mandarin as a foreign language. First, it is important for teachers and instructors to stimulate and maintain students' motivational level in the classroom and sustain their learning efforts after graduating and when they join the workforce. Thus, a knowledge of the integrative and instrumental motivational orientations of the students would greatly assist instructors and syllabus designers, curriculum planners in the planning, designing and development of classroom curriculum, program of study, instructional strategies, and learning materials which incorporates and promotes both types of motivations in learning Mandarin within and beyond the classroom setting. Second, in terms of attitudinal motivation which is associated with a distinct orientation/inclination/leaning toward teacher-specific sources, whereby teachers play an important role in making students have positive attitudes toward learning Mandarin, teachers need to create an interesting and conducive environment through student-centered, interactive, and fun learning with encouraging and constructive feedback.

\section{Conclusion}

The study showed that the students were generally highly motivated to learn Mandarin as a foreign language. The study's findings add to existing scholarly research and literature on motivational orientations in foreign language learning by providing further empirical evidence that students are not necessarily oriented towards integrative or instrumental motivation but have a combination of both motivations in learning a foreign language which was Mandarin in this present study. More importantly, students' attitudinal motivation was more pronounced than their integrative and instrumental motivations which suggests that students' attitudes are a crucial factor in the foreign language learning situation. Implication- 
wise, teachers should take cognizance of their students' motivational orientations and design appropriate instructional practices according to their motivation types to maintain and sustain their interests in learning Mandarin as a foreign language/ learning foreign languages. Teachers play an important role in ensuring their students have positive attitudes towards learning Mandarin by creating a conducive environment with more student- centered, enjoyable and interactive activities and encouraging feedback.

\section{Limitations and Future Research}

Current study involved Malay undergraduates from only one public university. Perhaps future research should include a larger sample of participants from other public and private universities to increase the generalizability and comparability of the study's findings with other institutions of higher learning. This study employed a quantitative research design. It is recommends that perhaps future research should use mixed method research design which combine both quantitative and qualitative research to investigate the relationship between motivational orientations and Mandarin language achievement. Futhermore, future researchers could conduct acomparative research on the motivational orientations in learning different foreign languages.

\section{References}

Abidin, M. J., Pour-Mohannadi, M., ve Alzwari, H. (2012). EFL students'attitudes towards learning English language: The case of Libyan secondary school students. Asian Social Science, 8(2), 119-134.

Zubairi, A. M., \& Sarudin, I. H. (2009). Motivation to learn a foreign language in Malaysia. GEMA Online Journal of Language Studies, 9(2), 73-87.

Ajape, K. O., Mamat, A., \& Azeez, Y. A. (2015). Students' Motivation and Attitude towards the Learning of Arabic Language: A Case Study of Arabic Students in Nigerian Universities. International Journal of Economics and Financial Issues, 5 (Special Issue), 122-127.

Arslan, H. O., Moseley, C., \& Cigdemoglu, C. (2011). Taking attention on environmental issues by an attractive educational game: Enviropoly. Procedia - Social and Behavioral Sciences, 28, 801-806. https://doi.org/10.1016/j.sbspro.2011.11.146

Atchade, M. P. (2002). The impact of learners' attitudes on second or foreign language learning. Sciences Sociales et Humaines, 4, 45-50.

Bartram, B. (2010). Attitudes to modern foreign language learning. London, UK: Continuum.

Brown, H. D. (2000). Principles of language learning and teaching ( $4^{\text {th }}$ ed.). Englewood Cliffs, NJ: Prentice-Hall.

Brown, H. D. (2007). Principles of language learning and teaching ( $5^{\text {th }}$ ed.). White Plains, NY: Pearson Education.

Chambers, G. (1999). Motivating Language Learners. Clevedon: Multilingual Matters.

Cheun, H. H. (2006). Problems encountered in teaching Chinese as a second language in Malaysia. Malaysia: New Era College. [In Chinese]

Choubsaz, Y., \& Choubsaz, Y. (2014). Motivational orientation and EFL learning: A study of Iranian undergraduate students. Procedia - Social and Behavioral Sciences, 98, 392397.

https://doi.org/10.1016/j.sbspro.2014.03.431

Chua, H. W., \& Azlan, K. M. A. (2019). Factors influencing foreign language learners' motivation in continuing to learn Mandarin. EDUCATUM Journal of Social Sciences, 5(1), 1-6. 
https://doi.org/10.37134/ejoss.vol5.1.1.2019

Clement, R., Dörnyei, Z., \& Noels, K. A. (1994). Motivation, self-confidence and group cohesion in the foreign language classroom. Language Learning, 44, 417-448.

Csizer, K., Ve Dörnyei, Z. (2005). The internal structure of language learning motivation and its relationship with language choice and learning effort. The Modern Language Journal, 89, 19-36.

Delgado, D. A. G. (2016). Survey study of Integrative and instrumental motivation in English language learning of first year students at Naresuan University International College (NUIC), Thailand. $6^{\text {th }}$ International Conference on Language, Education, and Innovation, $29^{\text {th }}-30^{\text {th }}$ October, 6-16. Retrieved from https://icsai.org/procarch/6iclei/6iclei-003.pdf

Deng, X. (2015). Community college students' motivational orientations and Chinese language learning (Unpublished PhD dissertation). University of Houston.

Dogan, Y., \& Tuncer, M. (2020). The role of attitudes in foreign language learning. In Y. Dogan (Ed.) Academic studies in foreign language education (pp. $83-94)$. Livre de Lyon Publisher.

Dörnyei, Z. (1990). Conceptualizing motivation in foreign -language learning. Language Learning, 40, 45-78.

Dörnyei, Z. (1994). Motivation and motivating in the foreign language classroom. Modern Language Journal, 78, 273-284.

Dörnyei, Z. (2003). Attitudes, orientations, and motivations in language learning: Advances in theory, research and applications. Language Learning, 53, 3-32.

Dörnyei, Z. (2005) The psychology of the language learner: Individual differences in second language acquisition. Mahwah, NJ: Lawrence Erlbaum.

Dörnyei, Z. (2009). Individual differences: Interplay of learner characteristics and learning environment. Language Learning 59 (Suppl. 1), 230-248.

Elyıldırım, S., \& Ashton, S. (2006). Creating positive attitudes towards English as a foreign language. English Teaching Forum, 4, 2-11.

Fakeye, D. (2010). Students' personal variables as correlates of academic achievement in English as a second language in Nigeria. Journal of Social Sciences, 22(3), 205-211.

Gardner, R. C. (1985). Social Psychology and Second Language Learning: The role of attitudes and motivation, London: Edward Arnold.

Gardner, R. C. (2005). Integrative Motivation and second language acquisition. Canadian Association of Applied Linguistics/Canadian Linguistics Association Joint Plenary Talk, May 30, 2005; London, Ontario. Retrieved January 10, 2021, from http://publish.uwo.ca/ gardner/docs/caaltalk5final.pdf

Gardner, R. C. (2010). Motivation and second language acquisition: The socio-educational model. New York: Peter Lang.

Gardner, R. C., Day, J. B., \& Maclntyre, P. D. (1992). Integrative motivation, induced anxiety, and language learning in a controlled environment. Studies in Second Language Acquisition, 14, 197-214.

Gardner, R. C., \& Lambert, W. (1972). Attitudes and motivation in second language learning. Rowley, MA: Newbury House.

Gardner, R. C., \& Maclntyre, P. D. (1991). An instrumental motivation in language study: Who says it isn't effective? Studies in Second Language Acquisition, 13, 57-72. 
Gardner, R. C., Tremblay, P. F., \& Masgoret, A. M. (1997). Toward a full model of second language learning: An empirical investigation. Modern Language Journal, 81, 344-362. https://doi.org/10.1111/j.1540-4781.1997.tb05495.x

Garrett, P. (2010). Attitudes to language. New York: Cambridge University Press.

Gholami, R., Allahyar, N., \& Rafik-Galea, S. (2012). Integrative Motivation as an Essential Determinant of Achievement: A Case of EFL High School Students. World Applied Sciences Journal, 17 (11): 1416-1424.

Gonzales, R. D. L. C. (2010). Motivational orientation in foreign language learning: The case of Filipino foreign language learners. TESOL Journal, 3, 3-28.

Halimah. (2012). Implementing language game "Snake and Ladders" to improve students" speaking ability. Undergraduate Thesis Program. University of Sebelas Maret.

Hong, Y. C., \& Ganapathy, M. (2017). To investigate ESL students' instrumental and integrative motivation towards English language learning in a Chinese school in Penang: Case study. English Language Teaching, 10(9):17-35. https://doi.org/10.5539/elt.v10n9p17

Lamb, M. (2004). Integrative motivation in a globalizing world. System, 32(1):3-19. https://doi.org/10.1016/j.system.2003.04.002

Lambert, W. E. (1974). Culture and language as factors in learning and education. In F. Aboud \& R. D. Meade (Eds.), Cultural factors in learning and education (pp.91-122). Bellingham: Western Washington State University.

Masgoret, A. M., \& Gardner, R. C. (2003). Attitudes, motivation, and second language learning: A meta-analysis of studies conducted by Gardner and associates.Language Learning, 53 (1), 123-163. https://doi.org/10.1111/1467-9922.00212

Merisuo-Storm, T. (2007). Pupils' attitudes towards foreign language learning and the development of literacy skills in bilingual education. Teaching and Teacher Education Journal, 23(2), 226-235.

Oroujlou, N., \& Vahedi, M. (2011). Motivation, attitude, and language learning. International Conference on Education and Educational Psychology, Procedia - Social and Behavioral Sciences 29, $994-1000$.

Özgür, B., \& Griffiths, C. (2013). Second language motivation. Procedia-Social and Behavioral Science, 70, 1109-1114.

Sayadian, S., \& Lashkarian, A. (2010). Investigating Attitude and Motivation of Iranian University Learners Toward English As A Foreign Language. Contemporary Issues in Education Research (CIER), 3(1), 137-148. https://doi.org/10.19030/cier.v3i1.170

Sheibani, O. B. (2012). Language Learning Motivation among Iranian Undergraduate Students. World Applied Sciences Journal, 19 (6): 838-846. DOI: 10.5829/idosi.wasj.2012.19.06.168

Setiyadi, A. B., Mahpul, \& Wicaksono, B. A. (2019). Exploring motivational orientations of English as foreign language (EFL) learners: A case study in Indonesia. South African Journal of Education, 39(1), 1-12.

Setiyadi, A. B., \& Sukirlan, M. (2016). Language attitude and motivation of the Islamic school students: How do Madrasa students of the academic year 2013-2014 in Indonesia perceive English, English teaching and learning and native speakers of English? Pertanika Journal of Social Science \& Humanities, 24(1):329-348.

Sung, K. Y., \& Wu, H. P. (2011). Factors influencing the learning of Chinese characters. International Journal of Bilingual Education and Bilingualism, 14(6), 683-700. 
Tan, T. G., \& Hoe, F. T. (2007). Research and contribution of University Technology MARA to the teaching Chinese language as a foreign language. Proceedings of 3rd International Forum on Chinese Language Teaching. National Taiwan Normal University.

Tan, T. G., \& Hoe, F. T. (2009). Vocabulary learning strategies of students learning mandarin as a foreign language. Proceedings of ILANNS 2009 Conference. MARA University of Technology Malaysia.

Tan, T. G., Ooi, A. K., \& Nizam, H. I. (2012). The Orientations for Learning Mandarin amongst Malay Undergraduate Students. International Journal of Humanities and Social Science. 2(12).

Wang, D. (2016). A Study on Students' Instrumental Motivation for English Learning in Chinese Universities. International Conference on Education, E-learning and Management Technology.

Youssef, A. M. S. (2012). Role of Motivation and attitude in introduction and learning of English as a foreign Language in Libyan high schools. International Journal of Linguistic, 4 (2), 366- 375.

Yu, Y. (2010). Attitudes of learners toward English: A case of Chinese college students. Ph.D., dissertation The Ohio State University, United States-Ohio. 